\title{
FIRST ATTEMPT TO CHARACTERIZE AN ASPERMATOGENIC SUBSTANCE IN THE SEMINAL VESICLE FLUIDS OF BULLS*
}

\author{
J. MATOUŠEK, R. STANĚK AND L. VESELSKÝ \\ Laboratory of Animal Genetics, Czechoslovak Academy of Sciences, \\ Liběchov, Czechoslovakia
}

(Received 25th March 1971, accepted 30th Fuly 1971)

\begin{abstract}
Summary. The biosynthesis of the aspermatogenic substance in the seminal vesicle fluid of bulls is dependent on the androgen level. The aspermatogenic substance is not present in sexually immature bulls; its synthesis can be evoked, however, by means of testosterone propionate. Castration is followed by a loss of libido and a decline in the production of fluids from the accessory genital glands; injections of testosterone propionate restore libido, the secretion of fluids and their aspermatogenic effect.

The aspermatogenic substance is thermostable, it is not digested by a number of enzymes including proteolytic enzymes, but it must evidently be bound to a protein complex in order to induce aspermatogenesis.

Rabbits developed several antibodies against bull vesicular fluid treated with enzymes, as judged by double diffusion, immunoelectrophoresis and haemagglutination tests. The number and character of the precipitation and haemagglutination antibodies in immunized animals did not differ whether the testes were damaged or undamaged. The fluorescence technique did not detect any binding of antibodies either to epididymal spermatozoa or to histological sections of the testes of rabbits and bulls.
\end{abstract}

\section{INTRODUGTION}

The aspermatogenic effect of all bovine accessory sexual gland fluids, including testicular fluid and blood serum, was analysed in a previous paper (Matoušek, 1969). The fraction causing aspermatogenesis in the testes of heterologous species was detected in the seminal vesicle fluid. Injections of bovine seminal vesicle fluid produced a decrease in the index weight of the testes, a disturbance of spermatogenesis and, in more severe cases, a distortion and contraction of the seminiferous tubules.

Further study was directed to the characterization of the substance(s) responsible for the aspermatogenic effect. The effect of sexual maturation and androgenic hormones on the synthesis of the aspermatogenic substance in the seminal vesicles, and the sensitivity of the substance towards temperature

* This paper reports on part of a project within the International Biological Programme. 
changes and towards enzymes were investigated, initial attempts being carried out at its isolation. The results obtained from these studies are presented in this paper.

\section{MATERIAL AND METHODS}

Collection of vesicular fuids and determination of the aspermatogenic effect

Bovine seminal vesicle fluid was collected at the slaughterhouse from healthy bulls of various ages (Matoušek, 1969) and from castrated bulls by means of an artificial vagina.

The determination of the aspermatogenic effect of a single intratesticular injection of the vesicular fluid of sexually immature, mature, castrated and testosterone-propionate-injected bulls, of vesicular fluid treated with enzymes and of the fluid fractions, was carried out by weight and histological analyses of testes from mice and guinea-pigs.

The index weight, i.e. testis weight in $\mathrm{g} \times 1000 / \mathrm{g}$ body weight, was used to express testis weight. The degree of testicular damage was assessed on a scale from 0 (normal histological appearance) to 4 (disappearance of all cells of the spermatogenic layers and of the convoluted tubules) 35 days after intratesticular injections (Matoušek, 1969).

Each of the tested fluids or vesicular fluid fractions was injected into the testes of four mice and two guinea-pigs. The dose injected was $0.02 \mathrm{ml}$ for mice and $0.2 \mathrm{ml}$ for guinea-pigs. The fractions were administered by resuspending $40 \mathrm{mg}$ freeze-dried and dialysed material in $1 \mathrm{ml} \mathrm{0.9 \%} \mathrm{NaCl}$. Alcohol-ether fractions (precipitates and extracts) and enzymatically-split fractions of vesicular fluid were resuspended in $0.9 \% \mathrm{NaCl}$ to give a 3 to $4 \%$ concentration of proteins. Protein concentration was determined by the biuret procedure.

Each enzyme-treated fluid was administered subcutaneously to two rabbits, at a dose of $1 \mathrm{ml}$ per injection, the number of injections ranging from four to twenty-two at 2- to 11-week intervals. The antispermatogenic effect of the administered fluid was investigated by measuring the amount of the ejaculate and the number of spermatozoa per ejaculate. Ejaculates were obtained from rabbits by means of an artificial vagina. Some rabbits were hemicastrated at the time of spermatogenic depression and the testis was examined histologically.

\section{Injections of testosterone propionate into bulls}

The dependence of the biosynthesis of the aspermatogenic substance in the seminal vesicles on androgenic hormones was investigated in four bulls.

(1) Two bulls were treated at the age of 2 to 4 months with $50 \mathrm{mg}$ testosterone propionate (Spofa, Prague), and at the age of 4 to 6 months with $100 \mathrm{mg}$ per injection twice a week. They were killed at the age of 6 months. The developmental stage of the spermatogenic epithelium of the testes in these two bulls was determined histologically, and the antispermatogenic effect of their vesicular fluid was measured by a single intratesticular injection of this fluid into two guinea-pigs.

(2) Two bulls were castrated at the age of $3 \frac{1}{2}$ years and their ejaculates were collected into an artificial vagina. When Bull 717 stopped ejaculating accessory 
genital gland fluids, daily injections of $50 \mathrm{mg}$ testosterone propionate were given. Injections were continued until the bull began ejaculating accessory genital gland fluids again ( 2 to 4 weeks). After repeated loss of fluids, the procedure was repeated. The fluids ejaculated into the artificial vagina were investigated for protein content and for aspermatogenic effect by means of intratesticular injections into mice and guinea-pigs.

\section{Sensitivity of the aspermatogenic substance towards temperature change and enzymatic action}

A mixture of vesicular fluids from twenty bulls was heated for $30 \mathrm{~min}$ in a water bath to 56,65 or $75^{\circ} \mathrm{C}$. It was also frozen eight times to $-20^{\circ} \mathrm{C}$ and repeatedly thawed to room temperature.

The vesicular fluid was treated with papain (3.4.4.10), ficin (3.4.4.5), trypsin (3.4.4.4), chymotrypsin (3.4.4.5), lysozyme (3.2.1.17), pronase, $\alpha$-amylase (3.2.1.1), $\beta$-amylase (3.2.1.2) and hyaluronidase (4.2.99.1) (KochLight Laboratories Ltd, England) according to the method of Amano \& Behrman (1968). The concentration of the enzyme was $20 \mathrm{mg} / \mathrm{ml}$ phosphate buffer, $\mathrm{pH} \mathrm{7 \cdot 1}$. After enzymatic splitting $\left(24 \mathrm{hr}\right.$ at $37^{\circ} \mathrm{C}$ ), alcohol-ether was added to the mixture of vesicular fluid and enzyme and both precipitate and extract suspended in $0.9 \% \mathrm{NaCl}$ were used for study.

\section{Methods of fractionation of vesicular fluid}

Alcohol-ether method. Vesicular fluid was dialysed against phosphate buffer,

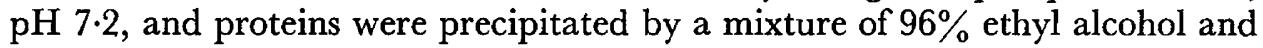
ether $(3: 1)$ at a ratio of $1: 5$. The filtered precipitate was cleared of the rest of alcohol-ether by air drying at laboratory temperature. Alcohol-ether was removed from the extract by submerging the sample into a water bath at 60 to $63^{\circ} \mathrm{C}$. Precipitate and extract were resuspended in $0.9 \% \mathrm{NaCl}$ to give a 3 to $4 \%$ concentration of proteins.

Ammonium sulphate method. Vesicular fluid was diluted with an equal volume of redistilled water and the $\mathrm{pH}$ was adjusted to $7 \cdot 0$ by means of $1 \mathrm{~m}-\mathrm{NaOH}$. Ammonium sulphate was added to a concentration of $1.5 \mathrm{~m}$. After $24 \mathrm{hr}$, the mixture was centrifuged and the precipitate obtained was designated ASIp; after resuspension in distilled water, it was dialysed for $48 \mathrm{hr}$ against water and freeze dried. Ammonium sulphate was added to a concentration of $2 \mathrm{~m}$ to the supernatant and the resulting precipitate was designated ASIIp and the supernatant ASIIs. By the further addition of ammonium sulphate to a concentration of $2 \cdot 5,3$ and $3.5 \mathrm{M}$ to the corresponding supernatants II, III and IV, precipitates and supernatants were gained which were designated ASIII, IV and $\mathrm{V}$, respectively.

Rivanol (6,9-diamino-2-ethoxyacridinelactate)-ammonium sulphate method. After diluting vesicular fluid with an equal volume of redistilled water, the $\mathrm{pH}$ was adjusted to 8.0 by means of $1 \mathrm{M}-\mathrm{NaOH}$, and part of the proteins was precipitated from the solution by adding an equal volume of $1.68 \%$ rivanol. After centrifugation, the precipitate, designated RIp, and the supernatant, RIs, were obtained.

Precipitate $\mathrm{RI}$ was resuspended in $0.9 \% \mathrm{NaCl}$ to the volume of the original 
mixture, and rivanol was precipitated by adding crystalline $\mathrm{NaCl}$. After centrifugation, a supernatant was obtained to which ammonium sulphate was added until it reached a concentration of $2.45 \mathrm{~m}$ in the solution. After $18 \mathrm{hr}$ at $5^{\circ} \mathrm{C}$, the supernatant was centrifuged and the precipitate, RIIp, and the supernatant, RIIs, were gained. Precipitate RII was dissolved in $0.9 \% \mathrm{NaCl}$, dialysed against water and freeze dried. Supernatant RII was also subjected to dialysis and freeze drying. The same procedure was applied to the supernatant $\mathrm{RI}$ which, after adjustment of the $\mathrm{pH}$ to 7.0 and the removal of rivanol, yielded precipitate RIIIp and supernatant RIIIs.

Chromatography on Sephadex $G-100$. Vesicular fluid was diluted 1:4 with ammonium carbonate ( $\mathrm{pH} 7 \cdot 85)$. Chromatographic separation was carried out on a column $6 \times 91 \mathrm{~cm}, 0.1 \mathrm{M}$-ammonium carbonate being used as eluant. The flow rate amounted to $54 \mathrm{ml} / \mathrm{hr}$ and fractions were collected at 20-min intervals. After chromatographic separation, the fractions with separated proteins were dialysed for $48 \mathrm{hr}$ against distilled water and freeze dried. The protein content was determined spectrophotometrically at $280 \mathrm{~nm}$.

\section{Electrophoretic analysis of fractions of vesicular fuid}

Electrophoretic separation was carried out in starch gel in a glacial acetic acid + formic acid buffer ( $\mathrm{pH} 1.7$ ) according to the method of Aschaffenburg (1966). Urea (47 g/120 ml of buffer) was added to prevent formation of protein aggregates. Electrophoresis was carried out at 300 to $350 \mathrm{~V}$ and 42 to $47 \mathrm{~mA}$ for about $16 \mathrm{hr}$. The gels were cooled with running water.

\section{Detection of antibodies}

The production of antibodies in rabbits immunized subcutaneously was investigated by means of the haemagglutination test (Stavitský, 1954), the agar-gel double diffusion technique (1\% agar-gel in borate buffer), microimmunoelectrophoresis (Scheidegger, 1955), and direct and indirect fluorescent methods (Batty \& Walker, 1967).

The vesicular fluid used as antigen for the haemagglutination test was freed from haemolytic factor by means of absorption with bovine ampullary spermatozoa. Epididymal spermatozoa and ultrathin sections $(4 \mu \mathrm{m})$ of testes from bulls and rabbits were used for fluorescent tests.

\section{RESULTS}

The effect of sexual maturation and androgen hormones on biosynthesis of the antispermatogenic substance

Vesicular fluid from sexually immature bulls (4 to 6 months old with testicular tissue differentiated maximally to the spermatocyte stage) did not evoke symptoms of aspermatogenesis when injected into the testes of four mice and eight guinea-pigs.

When spermatozoa appeared in the testes of maturing bulls, their vesicular fluid, which already contained the antispermatogenic substance, also caused the death of some of the injected animals. Out of seven guinea-pigs treated with a single intratesticular injection of $0.2 \mathrm{ml}$ fluid, four died within 3 days. The 
injected testes of the three remaining guinea-pigs 35 days after injection had an index weight of $0.62 \pm 0.04$, and their seminiferous tubules contained only spermatogonia and sporadically occurring spermatocytes.

The aspermatogenic effect of vesicular fluid, however, is not dependent on the degree of spermatogenesis. The testes of two young bulls which were injected with testosterone propionate at 2 to 6 months only contained cells up to the primary spermatocyte stage at 6 months, but the vesicular fluid of both contained the aspermatogenic substance. The testes from four guinea-pigs injected with fluid from these young bulls had a significantly lower index weight $(1.09 \pm 0.09)$ and the degeneration of the testicular epithelium reached Grade 3 to 4 .

In two bulls, castrated at the age of $3 \frac{1}{2}$ years, the accessory genital gland fluids (obtained by ejaculate collection from an artificial vagina) contained the antispermatogenic substance almost until the ejaculatory capacity disappeared.

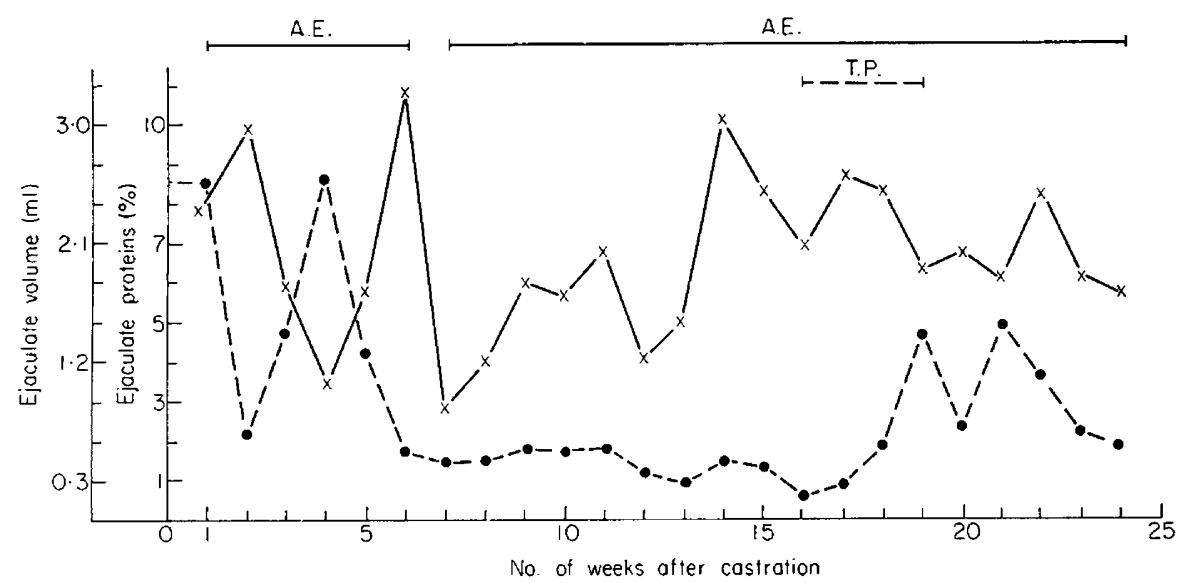

TExT-FIG. 1. Ejaculate characteristics of the castrated Bull 715. Volume of ejaculated fluids $(-)$, percentage of proteins in ejaculated fluids $(-----)$, their aspermatogenic effect (A.E.) and the period of testosterone propionate application (T.P.).

After castration, one of these bulls (No. 715) ejaculated for a period of 16 weeks without any androgen treatment (Text-fig. 1). During this whole period, all ejaculated fluids except one possessed the aspermatogenic substance, even though the protein content was reduced from the original value of $8.45 \mathrm{~g} / 100$ $\mathrm{ml}$ biuret reactive material to values between $\mathrm{I}$ and $2 \mathrm{~g} / 100 \mathrm{ml}$. Testosterone propionate injections considerably increased the protein content but not the amount of ejaculated fluids in this bull (Text-fig. 1). Bull No. 717 stopped ejaculating fluids into the artificial vagina by 3 weeks after castration (Textfig. 2). Testosterone propionate injections regenerated the secretion of the accessory genital glands and also the antispermatogenic substance in these fluids. The suppression of accessory genital gland fluid production occurred three times within 7 months in Bull 717. Each time, the secretory capacity and the original protein content of the ejaculates were renewed by means of testosterone propionate and the antispermatogenic effect of the ejaculated fluids was proved (Text-fig. 2). 
The effect of different temperatures and enzymes on the antispermatogenic substance

Temperatures of 56,65 and $75^{\circ} \mathrm{C}$ did not alter the antispermatogenic effect of vesicular fluid. Injections of heated samples of the fluid into the testes of mice and guinea-pigs caused significant changes in the seminiferous tubules (Table 1). Fluid frozen and defrosted eight times still retained its antispermatogenic effect.

The substance was not affected by any of the enzymes which were used (Table 1). Alcohol-ether extracts of fluid treated with enzymes had a very weak antispermatogenic effect. Only the extract obtained by the action of lysozyme on the fluid was active (Table 1 ).

Some fractions of fluid were also tested for an antispermatogenic effect by subcutaneous injection into rabbits. The results confirmed those obtained by direct intratesticular injections into mice and guinea-pigs. All protein fractions obtained after enzymatic action with trypsin, chymotrypsin, papain, pronase and lysozyme and by precipitation with alcohol-ether dissolved in $0.9 \% \mathrm{NaCl}$

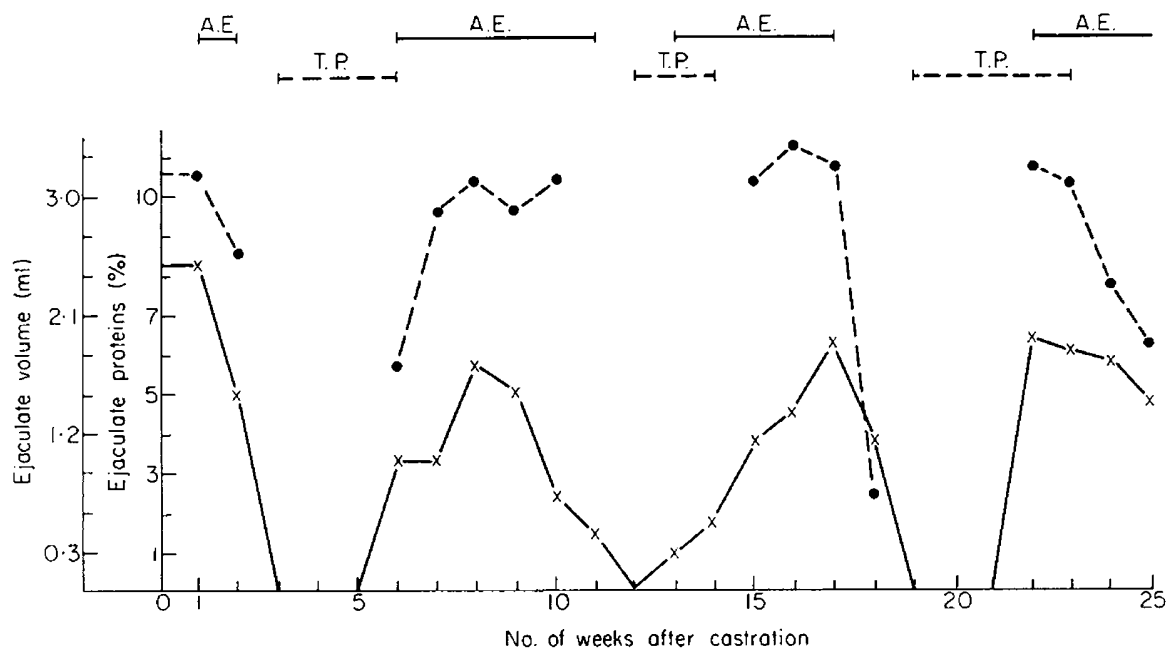

Text-Fig. 2. Ejaculate characteristics of the castrated Bull 717. Volume of ejaculated fluids ( - ), percentage of proteins in ejaculated fluids $(-----)$, their aspermatogenic effect (A.E.) and the period of testosterone propionate application (T.P.).

caused loss of libido in both, or at least one, of the two injected rabbits. Textfigure 3 illustrates the results obtained after injecting rabbit No. 580 with an alcohol-ether precipitate from fluid subjected to the action of lysozyme. Histological examination of testes from rabbits hemicastrated during sexual rest always showed impairment of spermatogenesis. In some tubules, spermatogenic cells were present up to the secondary spermatocyte stage (Pl. 1, Fig. 1).

Frg. 1. Cross section of rabbit testis after subcutaneous injections with alcohol-ether precipitate of bull seminal vesicle fluids treated by lysozyme. Only spermatogonia are visible in the seminiferous tubules shown. $\times 220$.

FrG. 2. Electrophoretic separation of bull seminal vesicle fluids (SVFB) and their fractions on starch gel. (1) Mixture of SVFB, (2) alcohol-ether precipitate of SVFB treated by pronase, (3) Peak 2 after chromatographic fractionation of SVFB, (4) Peak 4 after chromatographic fractionation of SVFB, (5) alcohol-ether extract of SVFB treated by chymotrypsin, (6) supernatant V (ASVs) after ammonium sulphate precipitation of SVFB, (7) Peak 5 after chromatographic fractionation of SVFB (negative in AE). 
PLATE 1

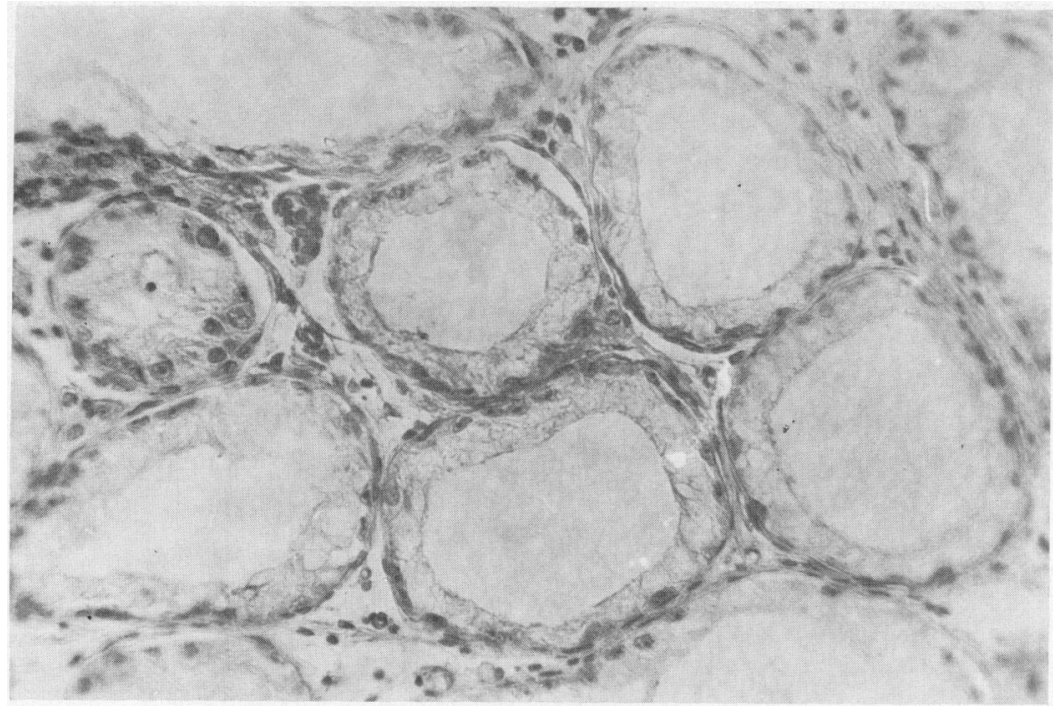

FIG. 1

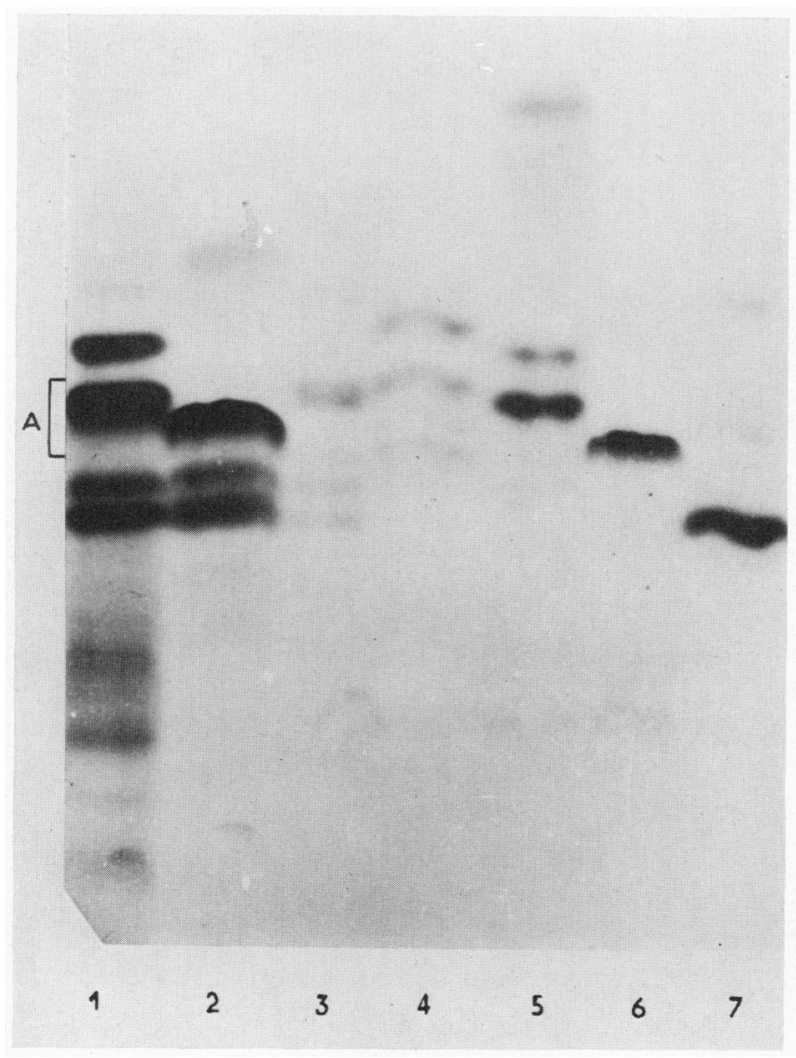

(Facing p. 184)

FIG. 2 
Fluid extracts treated with lysozyme, chymotrypsin and papain, also induced aspermatogenesis in rabbits, but it was necessary to double or treble the injection doses compared to those required with the corresponding precipitates: precipitates caused aspermatogenesis after four to ten injections; enzymetreated extracts after ten to twenty-two injections.

TABLE 1

INFLUENCE OF TEMPERATURE AND ENZYMES ON THE ASPERMATOGENIC AGTIVITY OF THE SEMINAL VESIGLE FLUID OF BULLS

\begin{tabular}{|c|c|c|c|c|}
\hline \multirow{3}{*}{ Temperature and enzymatic treatment } & \multicolumn{4}{|c|}{ Aspermatogenic activity } \\
\hline & \multicolumn{2}{|c|}{ Index weight of testes } & \multicolumn{2}{|c|}{ Degree of testis damage } \\
\hline & Mice & Guinea-pigs & Mice & Guinea-pigs \\
\hline $\begin{array}{l}\text { Control }(0.9 \% \text { NaCl }) \\
\text { SVFB without heating } \\
\text { SVFB heated to } 56^{\circ} \mathrm{G} \\
\text { SVFB heated to } 65^{\circ} \mathrm{C} \\
\text { SVFB heated to } 75^{\circ} \mathrm{C} \\
\text { SVFB frozen and thawed eight times } \\
\text { SVFB* papain-precipitate } \\
\text { SVFB* papain-extract } \\
\text { SVFB* ficin-precipitate } \\
\text { SVFB* ficin-extract } \\
\text { SVFB* trypsin-precipitate } \\
\text { SVFB* trypsin-extract } \\
\text { SVFB* chymotrypsin-precipitate } \\
\text { SVFB* chymotrypsin-extract } \\
\text { SVFB* pronase-precipitate } \\
\text { SVFB* pronase-extract } \\
\text { SVFB* lysozyme-precipitate } \\
\text { SVFB* lysozyme-extract } \\
\text { SVFB* } \alpha \text {-amylase-precipitate } \\
\text { SVFB* } \alpha \text {-amylase-extract } \\
\text { SVFB* } \beta \text {-amylase-precipitate } \\
\text { SVFB* } \beta \text {-amylase-extract } \\
\text { SVFB* hyaluronidase-precipitate } \\
\text { SVFB* hyaluronidase-extract }\end{array}$ & $\begin{array}{l}3 \cdot 30 \\
1 \cdot 03^{*} \\
1 \cdot 14^{*} \\
1 \cdot 26^{*} \\
1 \cdot 34^{*} \\
1 \cdot 27^{*} \\
1 \cdot 41^{*} \\
2 \cdot 39^{*} \\
1 \cdot 68^{*} \\
2 \cdot 53 \\
1 \cdot 46^{*} \\
3 \cdot 09 \\
1 \cdot 45^{*} \\
3 \cdot 16 \\
1 \cdot 31^{*} \\
3 \cdot 36 \\
1 \cdot 23^{*} \\
1 \cdot 34^{*} \\
1 \cdot 57^{*} \\
2 \cdot 38 \\
1 \cdot 70^{*} \\
3 \cdot 28 \\
1 \cdot 38^{*} \\
3 \cdot 22\end{array}$ & $\begin{array}{l}2 \cdot 55 \\
0.63^{*} \\
0.71^{*} \\
0.35^{*} \\
1.05^{*} \\
0.84^{*} \\
0.68^{*} \\
1.89 \\
0.64^{*} \\
2.08 \\
0.97^{*} \\
2 \cdot 16 \\
1 \cdot 20 \\
1.62 \\
0.61^{*} \\
2 \cdot 49 \\
0.57^{*} \\
0.72^{*} \\
0.54^{*} \\
1.52 \\
0.90^{*} \\
2.48 \\
1.12^{*} \\
2.52\end{array}$ & $\begin{array}{l}0 \\
4 \\
3 \text { to } 4 \\
4 \\
4 \\
3 \text { to } 4 \\
3 \text { to } 4 \\
0 \text { to } 1 \\
3 \text { to } 4 \\
1 \text { to } 2 \\
2 \text { to } 4 \\
0 \text { to } 1 \\
2 \text { to } 4 \\
0 \\
2 \text { to } 4 \\
0 \\
4 \\
1 \text { to } 2 \\
3 \text { to } 4 \\
0 \text { to } 1 \\
2 \text { to } 4 \\
0 \\
2 \text { to } 3 \\
0\end{array}$ & $\begin{array}{c}0 \\
4 \\
4 \\
4 \\
3 \text { to } 4 \\
4 \\
3 \text { to } 4 \\
0 \text { to } 1 \\
4 \\
0 \text { to } 2 \\
1 \text { to } 2 \\
0 \text { to } 1 \\
2 \text { to } 3 \\
0 \text { to } 2 \\
3 \text { to } 4 \\
0 \\
3 \text { to } 4 \\
1 \text { to } 3 \\
3 \text { to } 4 \\
0 \text { to } 1 \\
2 \text { to } 3 \\
0 \\
2 \text { to } 3 \\
0\end{array}$ \\
\hline
\end{tabular}

SVFB $=$ bull seminal vesicle fluids.

* Statistically highly significant, $P<0 \cdot 01$.

The suppression of spermatogenesis was reversible. After 12 to 28 weeks, even in the case of a unilaterally castrated rabbit, sexual activity including the capacity to ejaculate spermatozoa was regained (Text-fig. 3 ).

\section{Aspermatogenic effect of vesicular fluid after fractionation}

It is evident from the results of fluid fractionation that the antispermatogenic substance is bound to a protein complex (Table 2). It does not pass through the dialysis membrane but forms a portion of the proteins obtained by precipitating fluid with alcohol-ether, 1.5 to $3 \mathrm{M}$-ammonium sulphate, and rivanol.

However, even after ammonium-sulphate-induced precipitation of the proteins causing aspermatogenesis, the supernatant still contains a protein with similar activity. In starch-gel electrophoresis, this fluid forms a similar pattern to that formed by the alcohol-ether precipitate of vesicular fluid treated with 


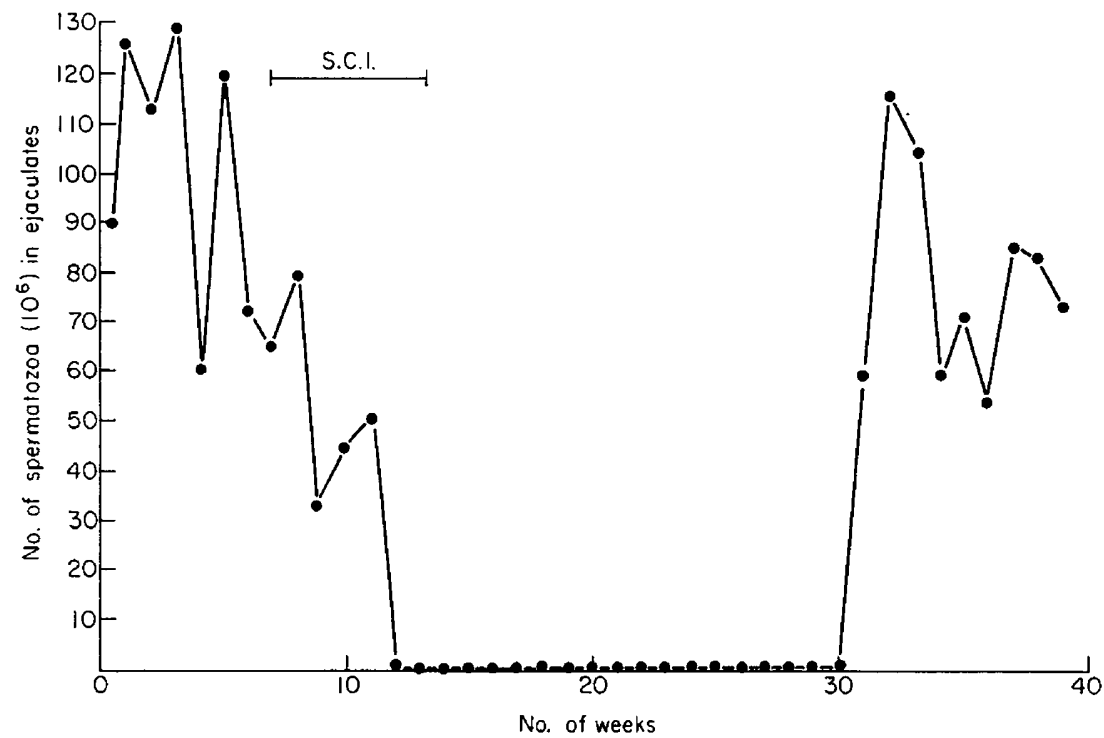

TEXT-FIG. 3. Ejaculate characteristics of the Rabbit 580 injected with the alcohol-ether precipitate of bull seminal vesicle fluids treated by lysozyme. (Period of the subcutaneous injections: S.C.I.)

TABLE 2

ASPERMATOGENIG AGTIVITY OF SEMINAL VESIGLE FLUID OF BULLS AFTER THEIR FRACTIONATION

\begin{tabular}{|c|c|c|c|c|c|}
\hline \multirow{3}{*}{ Fractionation method } & \multirow{3}{*}{$\begin{array}{c}\text { Designa- } \\
\text { tion of } \\
\text { fraction }\end{array}$} & \multicolumn{4}{|c|}{ Aspermatogenic activity } \\
\hline & & \multicolumn{2}{|c|}{ Index weight of testes } & \multicolumn{2}{|c|}{ Degree of testis damage } \\
\hline & & Mice & Guinea-pigs & Mice & Guinea-pigs \\
\hline 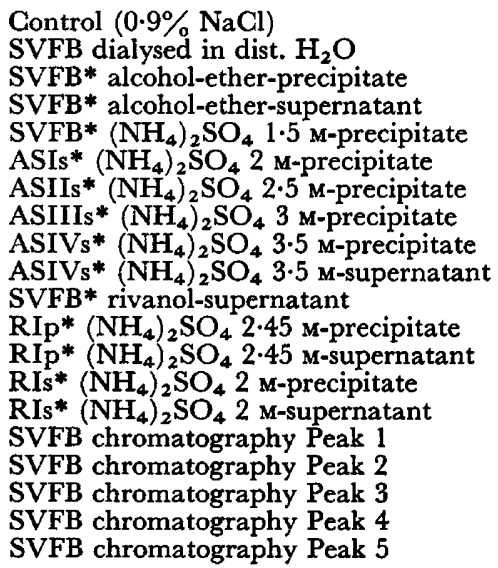 & $\begin{array}{l}\text { Contr } \\
\text { Dial } \\
\text { AEp } \\
\text { AES } \\
\text { ASIp } \\
\text { ASIIp } \\
\text { ASIIIp } \\
\text { ASIVp } \\
\text { ASVp } \\
\text { ASVs } \\
\text { RIs } \\
\text { RIIp } \\
\text { RIIs } \\
\text { RIIIp } \\
\text { RIIIs } \\
\text { CH1 } \\
\text { CH2 } \\
\text { CH3 } \\
\text { CH4 } \\
\text { CH5 }\end{array}$ & $\begin{array}{l}3.30 \\
1.07^{*} \\
1.13^{*} \\
2 \cdot 94 \\
1.09^{*} \\
0 \cdot 98^{*} \\
1.08^{*} \\
1.58^{*} \\
2 \cdot 82 \\
1.56^{*} \\
1.46^{*} \\
1.23^{*} \\
1.55 \\
1 \cdot 47^{*} \\
1 \cdot 76 \\
2.52 \\
1.21^{*} \\
1.27^{*} \\
1.16^{*} \\
2.96\end{array}$ & $\begin{array}{l}2 \cdot 55 \\
0 \cdot 40^{*} \\
0 \cdot 68^{*} \\
2 \cdot 50 \\
-\overline{0.58^{*}} \\
0 \cdot 62^{*} \\
0 \cdot 73^{*} \\
\overline{-} \\
\overline{1} \cdot 62 \\
0 \cdot 56^{*} \\
2 \cdot 14 \\
2 \cdot 04 \\
1 \cdot 89 \\
2 \cdot 38 \\
1 \cdot 18^{*} \\
1 \cdot 53^{*} \\
1 \cdot 04 \\
1.93\end{array}$ & $\begin{array}{l}0 \\
4 \\
4 \\
0 \text { to } 1 \\
4 \\
4 \\
4 \\
2 \text { to } 4 \\
0 \text { to } 2 \\
1 \text { to } 3 \\
2 \text { to } 3 \\
4 \\
0 \text { to } 3 \\
2 \text { to } 3 \\
0 \text { to } 2 \\
0 \text { to } 1 \\
11 \text { to } 3 \\
2 \text { to } 4 \\
3 \text { to } 4 \\
0 \text { to } 1\end{array}$ & $\begin{array}{c}0 \\
4 \\
3 \text { to } 4 \\
0 \\
\frac{4}{4} \\
3 \text { to } 4 \\
2 \text { to } 4 \\
- \\
1 \text { to } 2 \\
4 \\
0 \text { to } 1 \\
0 \text { to } 3 \\
0 \text { to } 2 \\
0 \\
2 \text { to } 3 \\
2 \\
1 \text { to } 2 \\
0 \text { to } 1\end{array}$ \\
\hline
\end{tabular}

SVFB $=$ bull seminal vesicle fluids.

* Statistically highly significant, $P<0.01$. 
pronase. The protein group in question is mainly the one concentrating on the gel in one or two strong zones, designated A (Pl. 1, Fig. 2). Electrophoretic analysis of the other fractions showed that a significant antispermatogenic effect was present in those fractions (including alcohol-ether precipitates and extracts of fluid treated with enzymes) which had part of their proteins in location A.

After chromatographic separation of fluid on Sephadex G-100, the antispermatogenic substance was contained in three peaks out of five. These peaks (Text-fig. $4-\mathrm{CH}_{2}, \mathrm{CH}_{3}$, and $\mathrm{CH}_{4}$ ) display protein staining in zone A after starch-gel electrophoresis.

\section{Antibodies after injections}

One-ml doses of alcohol-ether extract of vesicular fluid injected twelve times into two rabbits induced antibodies reacting in two and three lines on double

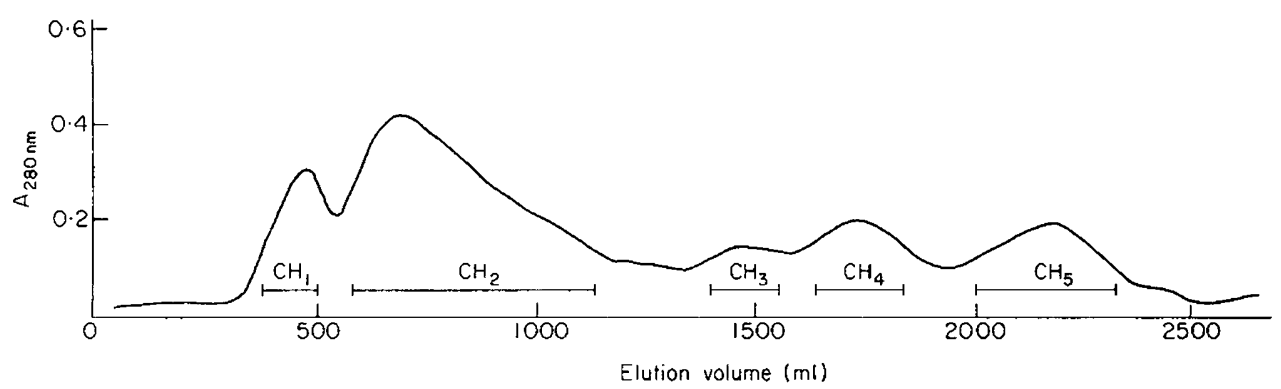

TEXT-FIG. 4. Chromatography of the seminal vesicle fluids of bulls on Sephadex G-100.

diffusion plates, in two arcs after immunoelectrophoresis ( $\alpha$-globulin region) and in the haemagglutination test at a titre of $1: 2$ and $1: 32$, respectively. The same alcohol-ether extracts of fluid treated with proteolytic enzymes induced very weak antibodies: no lines on double diffusion plates or arcs after immunoelectrophoresis and the titres of haemagglutinins ranged from 0 to $1: 4$.

Alcohol-ether precipitates of vesicular fluid induced antibodies showing six to eight lines on double diffusion plates and six to nine arcs after immunoelectrophoresis (in albumin and globulin regions); haemagglutination was observed at a titre of $1: 4$ to $1: 32$, respectively. Alcohol-ether precipitates of fluid treated with proteolytic enzymes induced rabbit antibodies showing one to five lines on double diffusion plates and two to five arcs after immunoelectrophoresis (in the $\alpha$ - and $\beta$-globulin regions); titres of $1: 4$ to $1: 16$ were found in haemagglutination tests. The other enzymes, $\alpha$ - and $\beta$-amylases and hyaluronidase, did not change the production of antibodies in injected rabbits.

There were no differences in the number or character of the precipitation and haemagglutination antibodies between immunized animals with damaged testes and those with normal ones.

It was not possible, by means of the fluorescence technique, to detect any antibody from the sera of eight injected rabbits, which reacted with epididymal spermatozoa or to show any reaction in histological sections of the testes of 
rabbits and bulls. The reactions were also negative with antisera obtained from animals with damaged testes. A positive reaction by means of fluorescence was obtained with antisera from rabbits immunized in the same way, using a mixture of fluids from bovine epididymides. The antibodies from these rabbits reacted with rabbit epididymal spermatozoa, the cells within the seminiferous tubules and even with the peripheral part of the tubular membrane.

\section{DISGUSSION}

One of the principal aims of the present work was to obtain information about the effect of androgenic hormones on the biosynthesis of the antispermatogenic substance. The absence of this substance from the vesicular fluid of sexually immature bulls, and its synthesis in prepuberal bulls treated with testosterone propionate, provide evidence for the dependence of the substance on androgenic hormones. Renewal of the secretion of accessory sex glands and of the synthesis of the substance in castrated bull No. 717 treated with testosterone propionate further confirms our hypothesis. The prolonged sexual activity and the biosynthesis of the antispermatogenic substance in castrated bull No. 715 in the absence of supplementary hormone is remarkable. It appears that in this bull the androgens secreted by the adrenal glands were sufficient.

The antispermatogenic substance in the seminal vesicle fluid of bulls is not only highly thermostable but also resistant towards the treatment with various enzymes. Fractionation of vesicular fluid suggested that the aspermatogenic effect is probably due to proteins. Nevertheless, none of the proteolytic enzymes used succeeded in splitting the substance. There can be two explanations for this phenomenon. Either the substance is not a protein, and the protein acts merely as carrier, or it is a protein that resists the enzymes used. The principal bearer of activity is evidently the protein region designated A, obtained after starch-gel electrophoresis of vesicular fluid and its fractions. Another chromatographic separation of fluid treated with pronase, not mentioned in this paper, showed that this protein region is not homogeneous but that it separates into at least two zones.

In an earlier paper (Matoušek, 1969), the aspermatogenic activity of vesicular fluid was considered from an immunological aspect and its cytotoxic aspect was mentioned only marginally. Our present results indicate the necessity of changing this order, and of adopting a more critical and circumspect approach towards the immunological version. Negative results on testes sections were obtained with fluorescence methods using sera of rabbits with induced aspermatogenesis. No difference in antibody response was observed in rabbits with damaged or undamaged testes after injections of the fractions of fluid. The sudden onset of degenerative changes in the testis after injection of the aspermatogenically-active fraction of the fluid does not suggest an immunological process. Degenerative changes could be observed in the seminiferous tubules by the 3rd day after intratesticular injection.

The possibility of a relationship between, or even the identity of, the aspermatogenic substance and the haemolytic factor which is also present in the seminal plasma of bulls (Millar, 1956) has been considered. On the basis of previous 
work (Matoušek \& Staněk, 1970; G. Kysilka, personal communication), we can assume that the two factors are not identical.

There is evidently a relationship between the aspermatogenic and antifertilizing effect of vesicular fluid. The antifertilizing effect of this fluid was manifested by a decrease in the number of embryos in mice and a reduction of egg-laying in hens (Matoušek \& Petrovská, 1969). Results obtained so far indicate that both of these phenomena are caused by one and the same substance. This problem will be dealt with in our next study. Other unsolved problems are the relationship of the antispermatogenic substance to the substance in seminal vesicle fluid that sensitizes spermatozoa to cold shock (Matoušek, 1968), and to the haemagglutinating factor in boar seminal plasma (Boursnell \& Coombs, 1966).

\section{REFERENCES}

Amano, V. \& Behrman, S. J. (1968) Immunochemical studies on human seminal plasma. II. Isolation and characterization of major antigens. Int. F. Fert. 13, 61 .

Aschaffenburg, R. (1966) Modified procedure of starch gel electrophoresis for $\beta$-casein phenotyping. 7. Dairy Sci. 49, 1284.

BAtTy, I. \& Walker, P. D. (1967) The use of the fluorescent labelled antibody technique for the detection and differentiation of bacterial species. Symposia Series in Immunobiological Standardization, 4, 72. Karger, Basel.

Boursnell, J. C. \& Coombs, R. R. A. (1966) A haemagglutinating factor in boar seminal plasma. 7. Reprod. Fert. 11, 139.

MATOǓ̌EK, J. (1968) Seminal vesicle fluid substance of bulls sensitizing spermatozoa to cold shock. VIth Cong. int. Reprod. Anim. Insem. Artif., Paris, 1, 553.

MATOUšEK, J. (1969) Effects on spermatogenesis in guinea-pigs, rabbits and sheep after their immunization with sexual organ fluids of bulls. F. Reprod. Fert. 19, 63.

Matoušek, J. \& Petrovská, E. (1969) Antifertilizing effect of the seminal vesicle fluid of bulls on females. 7. Reprod. Fert. 20, 189.

Matoušek, J. \& StanĚK, R. (1970) Haemolytic factor in bovine seminal vesicle fluid. II. First attempt at fractionation and enzymatic splitting. Anim. Blood Grps biochem. Genet. 1, 157.

MiLlaA, P. G. (1956) Observations on the presence of a haemolysin in bovine semen. Br. vet. F. 112, 106.

SchembGger, J. (1955) Une micro-méthode de l'immuno-électrophorèse. Int. Archs Allergy appl. Immun. $7,103$.

Stavrrskx́, A. B. (1954) Micromethods for the study of proteins and antibodies. I. Procedure and general applications of hemagglutination and hemagglutination-inhibition reactions with tannic acid and protein-treated red blood cells. F. Immun. 72, 360. 